\title{
ECOLOGY OF MARINE TUCUXI, SOTALIA GUIANENSIS, AND BOTTLENOSE DOLPHIN, Tursiops truncatus, in Baía Norte, Santa Catarina state, southern Brazil
}

\author{
Paulo A. C. Flores ${ }^{1,2 *}$ and Nelson F. Fontoura ${ }^{3}$
}

\begin{abstract}
Aвstract:The marine tucuxi (Sotalia guianensis) occurs in coastal waters of western Central and South America sympatric to the bottlenose dolphin (Tursiops truncatus) throughout its range. This paper presents information on ecology based on 228 marine tucuxi and 36 bottlenose dolphin sightings collected during 226 boat-based surveys conducted from 1993 to 2002 in Baía Norte

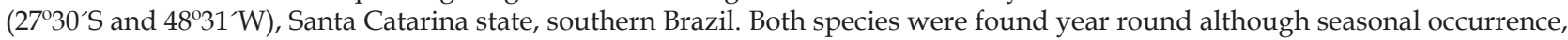
sighting indices, sightings per unit of effort as well as group size and composition were strongly different. These features were different for marine tucuxis but similar to bottlenose dolphins when compared to other areas. Marine tucuxis were only found in the western part of the bay while bottlenose dolphins occurred mostly in the eastern section. Distances between species' sightings on the same days averaged $6.9 \mathrm{~km}$. Observations were made of both dolphin species feeding on the same fish species, of tucuxis being displaced by bottlenose dolphins and of an adult tucuxi bearing tooth rakes likely to have been caused by bottlenose dolphin attacks. Spatial segregation was not clearly explained by the environmental variables analyzed, suggesting that biological features such as aggression or competition may be influencing tucuxi distribution and social structure in Baía Norte.
\end{abstract}

Resumo: O golfinho ou boto-cinza (Sotalia guianensis) ocorre em águas costeiras orientais da América do Sul e Central, simpátrico ao golfinho-nariz-de-garrafa (Tursiops truncatus) em toda sua distribuição. Este trabalho apresenta informações ecológicas baseadas em 228 avistagens de boto-cinza e 36 de golfinho-nariz-de-garrafa coletadas durante 226 levantamentos embarcados realizados entre

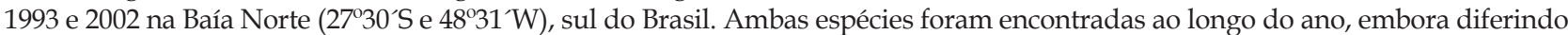
em ocorrência sazonal, índices de avistagens, avistagem por unidade de esforço, assim como apresentando distintos tamanho e composição de grupo. Estes aspectos foram diferentes para o boto-cinza, mas similares para o golfinho-nariz-de-garrafa quando comparados a outras áreas. O boto-cinza foi encontrado apenas na porção oeste da baía, enquanto o golfinho-nariz-de-garrafa ocorreu principalmente no setor leste. A distância média entre locais de avistagens das duas espécies quando estas ocorreram no mesmo dia foi de $6.9 \mathrm{~km}$. Ambas espécies foram observadas capturando ou se alimentando de mesmas espécies de peixes. Em uma ocasião um grupo de boto-cinza se retirou de área previamente ocupada devido à aproximação de golfinhos-nariz-de-garrafa, enquanto em outra oportunidade um boto-cinza grande (presumivelmente aduto) foi observado e fotografado com profundas e extensas marcas de dentes potencialmente causadas por um ataque de golfinho(s)-nariz-de-garrafa. A segregação especial não parece claramente explicada pelos fatores ambientais analisados, sugerindo que aspectos biológicos como agressão inter-específica e/ou competição podem estar influenciando a distribuição e a organização social do boto-cinza na Baía Norte.

Keywords: marine tucuxi, Sotalia guianensis, bottlenose dolphin, Tursiops truncatus, distribution, ecology, interspecific interactions, southern Brazil.

\section{Introduction}

Although occurring in coastal waters sympatric to the bottlenose dolphin (Tursiops truncatus) throughout its range, the marine tucuxi (Sotalia guianensis) rarely interacts with the former species (da Silva and Best, 1994; 1996; Flores, 2002). Feeding associations were recorded in Baía de Guanabara (22 $\left.45^{\prime} \mathrm{S}, 43^{\circ} 10^{\prime} \mathrm{W}\right)$, southeastern Brazil (Andrade et al., 1987), and Baía de Guaratuba (2551'S, 48 $40^{\prime} \mathrm{W}$ ), southern Brazil (Monteiro Filho et al., 1999). Apparent sexual and mating interactions were observed in Costa Rica $\left(9^{\circ} 37^{\prime} \mathrm{N}, 8^{\circ} 37^{\prime} \mathrm{W}\right)$ (AcevedoGutierrez et al., 2005) while an aggression event from bottlenose dolphins toward a tucuxi was observed in southern Brazil (Wedekin et al., 2004). Additionally, there is no information on the distribution patterns and related environmental features, group size and composition and other ecological aspects compared for both species in the same area.

The marine tucuxi is found mostly in estuaries, bays and other protected shallow coastal waters in the Western Atlantic of South and Central America from southern Brazil $\left(27^{\circ} 35^{\prime} \mathrm{S}, 48^{\circ} 35^{\prime} \mathrm{W}\right)$ to Nicaragua $\left(14^{\circ} 35^{\prime} \mathrm{N}\right.$, $\left.83^{\circ} 14^{\prime} \mathrm{W}\right)$, with possible records in Honduras $\left(15^{\circ} 58^{\prime} \mathrm{N}\right.$, 7954'W) (da Silva and Best, 1996; Flores, 2002). The bottlenose dolphin has a wide distribution in both coastal and offshore waters of all oceans and seas, with the exception of high latitudes (Wells and Scott, 1999). In Brazilian waters it probably occurs from the north/ northeastern to the south (Bastida et al., in press) notably in Santa Catarina and Rio Grande do Sul states where resident populations have been studied in estuaries and river systems (e.g. Dalla Rosa, 1999; Simões-Lopes and Fabian, 1999; Simões-Lopes et al., 1998).

\footnotetext{
${ }^{1}$ Laboratório de Dinâmica Populacional, Instituto de Biociências, Pontifícia Universidade Católica do Rio Grande do Sul, Porto Alegre, RS Brazil, and International Wildlife Coalition - Brazil.

${ }^{2}$ Current address: Instituto de Pesquisa \& Conservação de Golfinhos, Florianópolis, SC, Brazil and Centro Nacional de Pesquisa, Conservação e Manejo de Mamíferos Aquáticos - CMA, IBAMA AM. Rua Min. João Gonçalves de Souza, s/n, Distrito Industrial, Manaus, 69075-830 AM Brazil

* Corresponding author, e-mails: flores.p@terra.com.br and paulo.flores@ibama.gov.br.

${ }^{3}$ Depto de Biodiversidade e Ecologia, Faculdade de Biociências, Pontifícia Universidade Católica do Rio Grande do Sul. Av. Ipiranga, 6681 Prédio 12-C, sala 173, Porto Alegre, 90619-900 RS Brazil.
} 
In Baía Norte, Santa Catarina state, southern Brazil, the marine tucuxi occurs year round and is seen almost on a daily basis, exhibiting a restricted distribution and strong site fidelity, with individuals being reported to be resident for up to at least 10 years (e.g. Flores, 1999; 2003; Flores and Bazzalo, 2004). Bottlenose dolphins are apparently more widely distributed in the region but is less frequent in Baia Norte itself (Flores, 2003). We compared data collected over a 10 -year period on distribution, occurrence, group size and composition as well as environmental and ecological correlates of both species in Baía Norte.

\section{Methods}

\section{Study area}

Baía Norte and surrounding waters $\left(27^{\circ} 23^{\prime}-27^{\circ} 35^{\prime} \mathrm{S}\right.$, $48^{\circ} 33^{\prime}-48^{\circ} 30^{\prime} \mathrm{W}$ ), located on the southern Brazilian coast (Figure 1), are very shallow with depths usually less than $12 \mathrm{~m}$, except at the North channel (around 14m) and the strait connecting to Baía Sul (more than $25 \mathrm{~m}$ ). Only three species of small cetaceans have been sighted in the bay. The franciscana (Pontoporia blainvillei) was seen only three times over 10 years (Flores et al., 2000) while bottlenose dolphins are more frequently found (Flores, 2003). The marine tucuxi, however, is found year round almost on a daily basis and over long-term periods (> 10 years) in a resident, small, discrete population (e.g. Flores, 1999; Flores and Bazzalo, 2004).

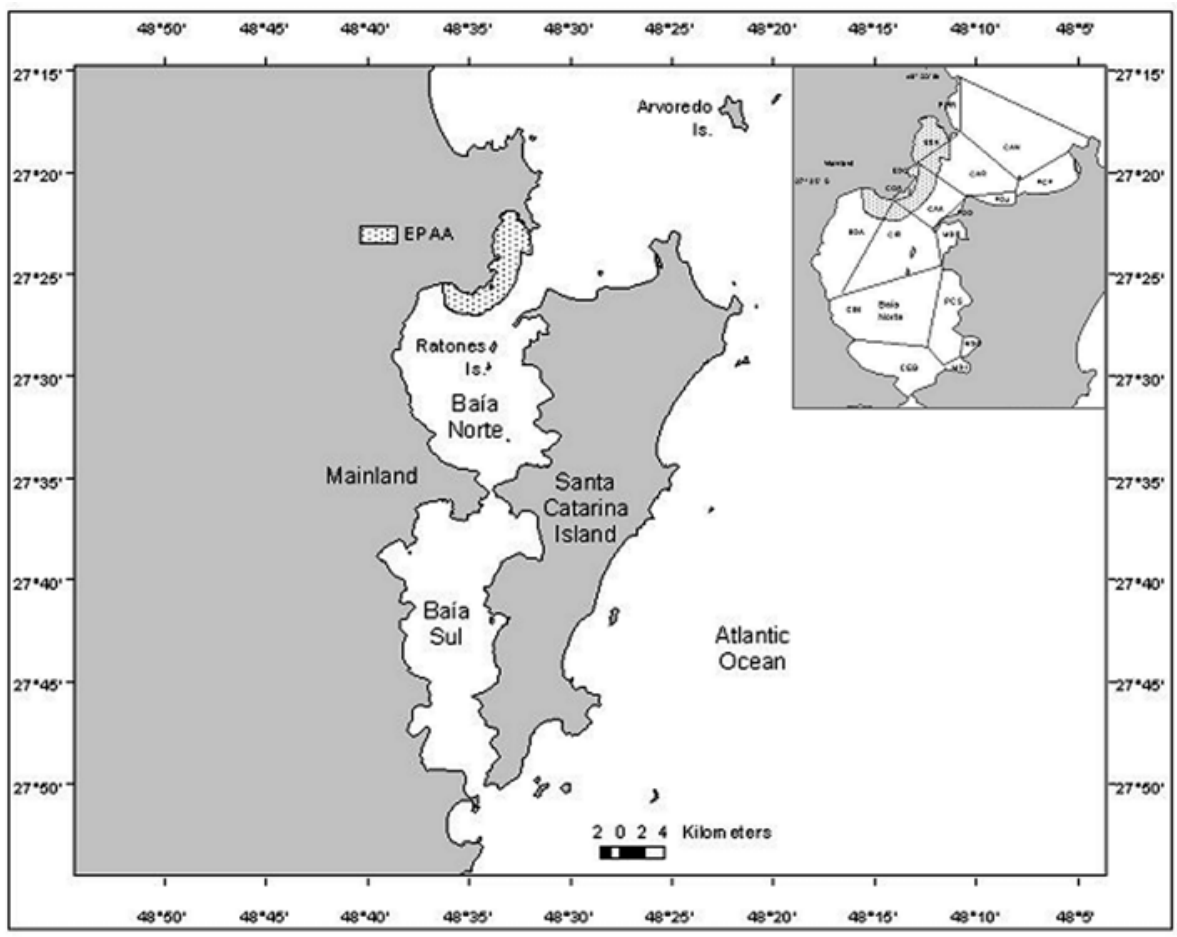

Figure 1. Study site including the Environmental Protection Area of Anhatomirim (EPAA - dotted area) and zones considered (insert).

\section{Field procedures}

Data were collected from boat surveys and included photo-identification, behavioral sampling and variable environmental measurements. Boats used were a $3 \mathrm{~m}$ long rigid hull inflatable powered by a $15 \mathrm{hp}$, two stroke, outboard engine during 1993-1995 and a 5m long rigid hull inflatable with either a 25hp, two stroke (1995-1999) or 30hp, four stroke, outboard engine from 1999 onwards. Photo-identification and boat based procedures including field effort for the tucuxi dolphin have been described elsewhere (Flores, 1999; 2003; Flores and Bazzalo, 2004). Although surveys were targeted at the marine tucuxi, whenever bottlenose dolphins were found the same methodology was applied. Because sea conditions may deteriorate in the afternoon, the time spent at the surveys ranged from 0:24 min. to 9:15 hours (mean $=4: 37 \mathrm{hs}$ ). This paper summarizes data on 226 surveys and over 1010hs of field effort in 1993-2002 (field effort combines survey effort and direct observation or focal sampling).

Two types of surveys were conducted: focal group survey and "random survey". Neither survey followed an established route. During focal-group surveys the same animals are observed and usually photographed until the end of the survey. "Random surveys" are conducted when a survey is resumed to other zones after leaving a sighting. This may occur when: (i) it is concluded that most individuals were photographed, (ii) the initial $5 \mathrm{~min}$. sampling is finished to increase the size of area surveyed afterwards, or (iii) weather or sea state conditions are poor or deteriorating as well as time is limited. In all three cases, weather and logistics allowing, a survey was resumed after a dolphin sighting to increase chances of having other sightings in the same survey. Once a group of dolphins was encountered, dolphin data were recorded at $5 \mathrm{~min}$. intervals and environmental variables were measured at initial dolphin sighting locations. The recorded dolphin data included time of day, location of dolphins, number of individuals in the group, group composition (adult, juvenile, calf, female), behavioral activity, and birds in association during feeding behavior. The environmental variables measured at each sighting location were, whenever possible, water temperature at $1 \mathrm{~m}$ depth, water transparency by Secchi disc and depth (with a handheld depth sounder). 
Locations of dolphins were determined by two different ways. Location was assigned a three letter code from the 18 zones defined by topographic references and easily identifiable from the boat (Flores, 1999) during 1993-2002 (Figures 1 and 2). Map plotting in nautical chart copies ( $n^{\circ} 1903$ of the Division of Hydrograph and Navigation, Brazilian Navy) and recording via GPS handheld device were additionally taken in 1996-2002. Boat and land-based opportunistic sightings were recorded similarly.

\section{Definitions}

The term 'sighting' was defined as the encounter with either a group or solitary animals during the course of a survey and thus represents the sampling unit. A group of dolphins refers to an aggregation of dolphins within visual range of the survey team and usually engaged in the same general activity/ behavior pattern. A group may contain individuals of all age classes.

Group size was determined by direct counting of individuals and it was classified and divided into 6 classes or categories. Each one was defined as follows: class 1 - one to 5 individuals, class 2 - six to 10 individuals, class $3-11$ to 20 individuals, class $4-21$ to 40 individuals, class $5-41$ to 60 individuals, and class $6-61$ to 80 individuals. Whenever possible an accurate count was obtained during sightings of small group sizes (classes 1 to 3 ).

The following age classes were distinguished. Adults were defined as large individuals estimated to be approximately $2 \mathrm{~m}$ long for marine tucuxis and 2.5 $3 \mathrm{~m}$ for bottlenose dolphins. The following applies to both species. A female was defined as any large animal with the continuous presence of a calf or a juvenile during at least five consecutive sightings. "Probable male" was defined as any large animal heavily scarred and with no calf in any sighting, comparable to what has been described for bottlenose dolphins by Smolker et al. (1992) and Tolley et al. (1995). However, it is recognized that this assumption is yet not proved for Sotalia. A calf was identified as an animal less than 2/3 the size of an associated larger animal and constantly accompanying one large individual presumed to be its mother. Newborns were distinguished by the presence of visible neonatal folds, usually darker color pattern in marine tucuxis, and a disproportionately large melon.

Seasons were defined as: Autumn, 21 March - 20 June; Winter, 21 June - 20 September; Spring, 21 September - 20 December; Summer, 21 December - 20 March.

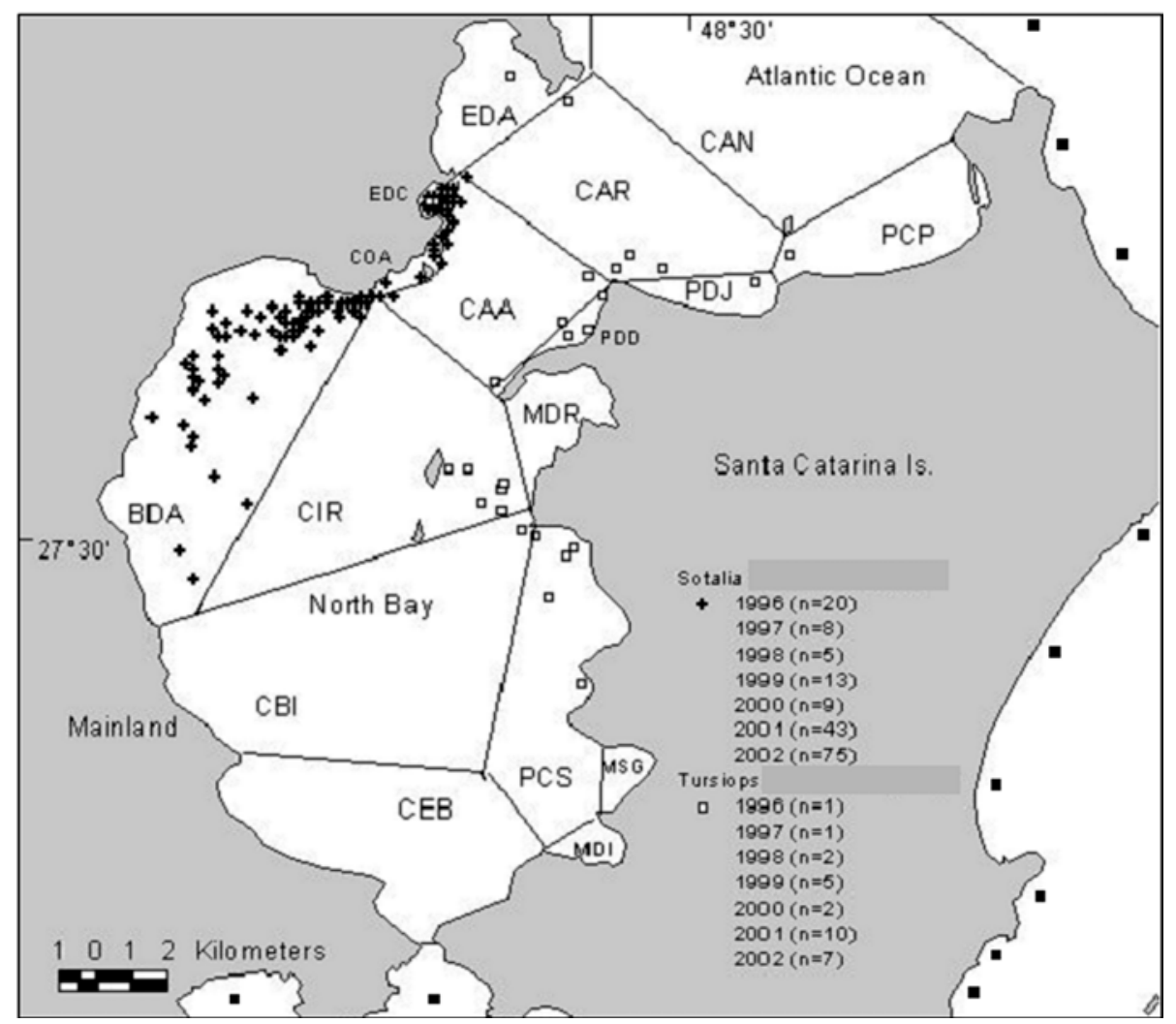

Figure 2. Sightings of marine tucuxi (Sotalia) $(\mathrm{n}=173)$ and bottlenose (Tursiops) $(\mathrm{n}=28)$ dolphins in Baía Norte, southern Brazil, during 170 boat surveys from February 1996 to December 2002. Solid squares represent bottlenose dolphin opportunistic sightings. Zones according to Flores (1999) and see also Figure 1. 


\section{Data analysis}

The distribution of dolphins was quantified through a Sighting Index by Zone $\left(S I_{\text {ZONE }}\right)$. This index represents the number of times a species was sighted in a given zone as a proportion of the total times it was sighted overall. It is calculated as $S I_{\mathrm{ZONE}}=S$ zone/S, where $S$ zone is the times the dolphin was sighted in any one zone and $S$ is the total number of times it was sighted in the study area. The Sighting Index by Zone, ranging from 0.0 to 1.0 was calculated for each year and the for the entire study period. A Sighting per Unit of Effort (SPUE) was also calculated as the number of sightings in every zone per hour of effort. All sighting locations collected during 1996-2002 were entered in ArcView 3.1 and the distance from tucuxi to bottlenose sightings in a given day was measured as the straight line between each sighting avoiding any landmass. The package BioEstat 2.0 was used for statistical analysis. Dolphin locations $\left(S I_{\mathrm{ZONE}}\right)$ were correlated to survey effort using the Spearman rank correlation. SPUE were compared between species using the Mann-Whitney U test. Differences in the environmental correlates (water temperature and turbidity, depth) between the two dolphin species were evaluated using the Mann-Whitney $U$ test. A Chi-Square test was used to verify difference of sightings frequency throughout seasons while ANOVA was applied for evaluating differences in group size and composition among seasons. All tests were applied at a 5\% significance level (Zar, 1999).

\section{Results}

\section{Database}

Marine tucuxis were found on all but six occasions and were recorded in multiple sightings in a single day on only eight days, totalling 228 tucuxi sightings. Only 36 sightings of bottlenose dolphins were obtained in 30 out of the 226 surveys, with up to four sightings on the same day. Concurrent sightings of both species were recorded on 19 surveys. Tucuxi were sighted between 6:30 to 15:00 and bottlenose dolphins from 7:45 to 17:40 local time.

\section{Distribution and occurrence patterns}

Marine tucuxis were highly restricted to the centralsouthern west sector of the bay, while the bottlenose dolphins were mostly found from the southern to the northern areas of the east sector with fewer sightings in central-northern west sector. Only bottlenose dolphins were recorded in opportunistic sightings in various places outside Baía Norte (Figure 2). Although seen in all years in Baía Norte, both species had different SPUE values (Figure 3) which were statistically significant (Mann-Whitney $\mathrm{U}, P=0.0005$ ).

Marine tucuxis occurred in eight zones and were consistently sighted in only two (zones EDC and BDA, $S I_{\mathrm{EDC}}=0.465$ and $S I_{\mathrm{BDA}}=0.351$ or a combined $S I=0.816$ ) out of the 18 zones surveyed (Figure 4). Bottlenose dolphins were sighted in 14 zones without any marked preference $\left(S I_{Z O N E}\right.$ ranging from 0.167 in CIR to 0.028 in seven zones - Figure 4). There was no correlation between marine tucuxi $S I_{Z O N E}$ and survey effort per zone (Spearman rank correlation, $r_{s}=0.0244, P=0.9543$ ).

Marine tucuxis were found year round every month while bottlenose dolphins were not encountered in March, April and October (Figure 5A). Sightings of tucuxi were evenly distributed throughout the seasons while bottlenose dolphins were seen less frequently in summer $(11.11 \%, \mathrm{n}=4$ sightings) and more commonly in winter $(38.89 \%, \mathrm{n}=14)$ than in spring $(27.78 \%, \mathrm{n}=10)$ and autumn $(22.22 \%, \mathrm{n}=8)$ (Figure 5B). However, no seasonal differences were found for sighting frequencies of bottlenose dolphins (Chi-Square, $\mathrm{P}=0.123$ ).

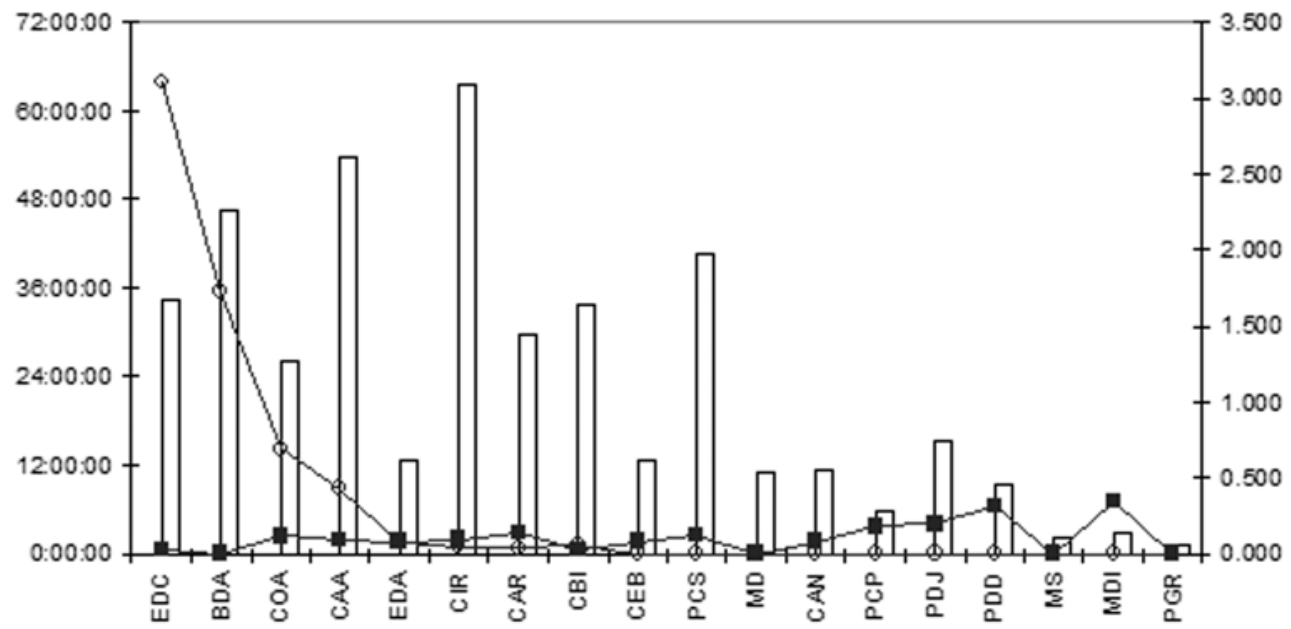

Figure 3. Distribution (Y-axes) of survey effort in hours (bars) and sighting per unit of effort (lines) by zones (X-axes) for the marine tucuxi (open circles) and bottlenose dolphin (solid squares) in Baía Norte, southern Brazil, during 1993-2002. Zones according to Flores (1999) and see also Figure 1. 


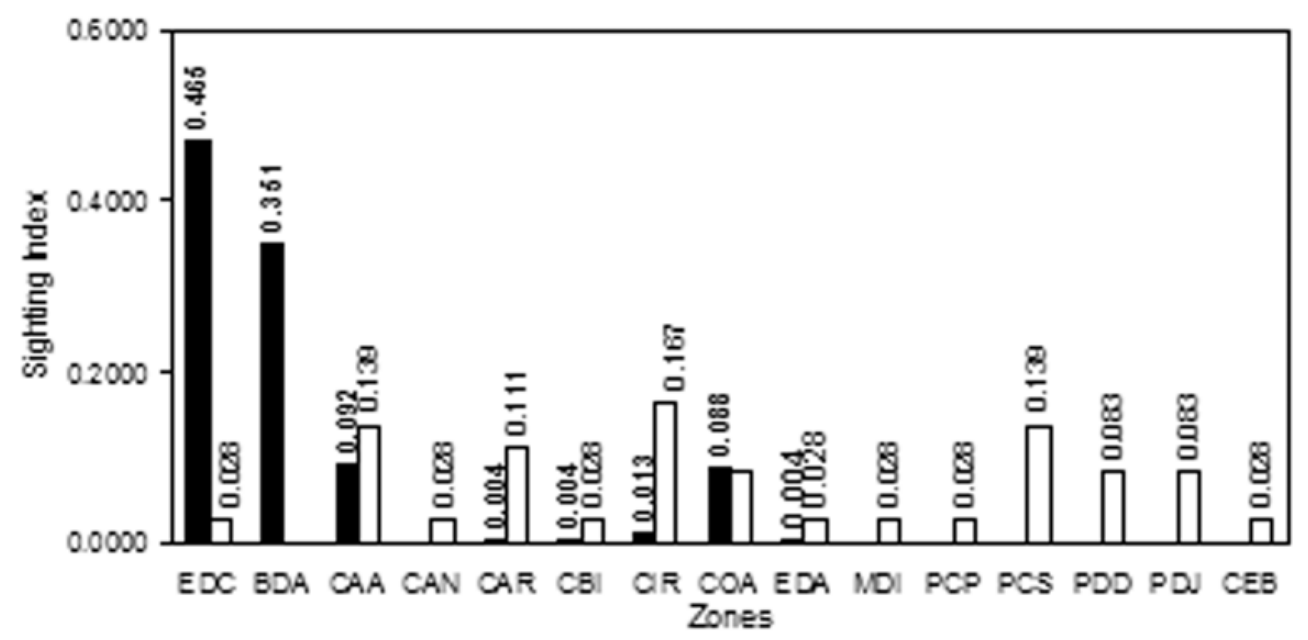

Figure 4. Zone Sighting Index of marine tucuxi (solid bars) and bottlenose (open bars) dolphins in Baía Norte, southern Brazil, during 1993-2002. Zones according to Flores (1999) and see also Figure 1.
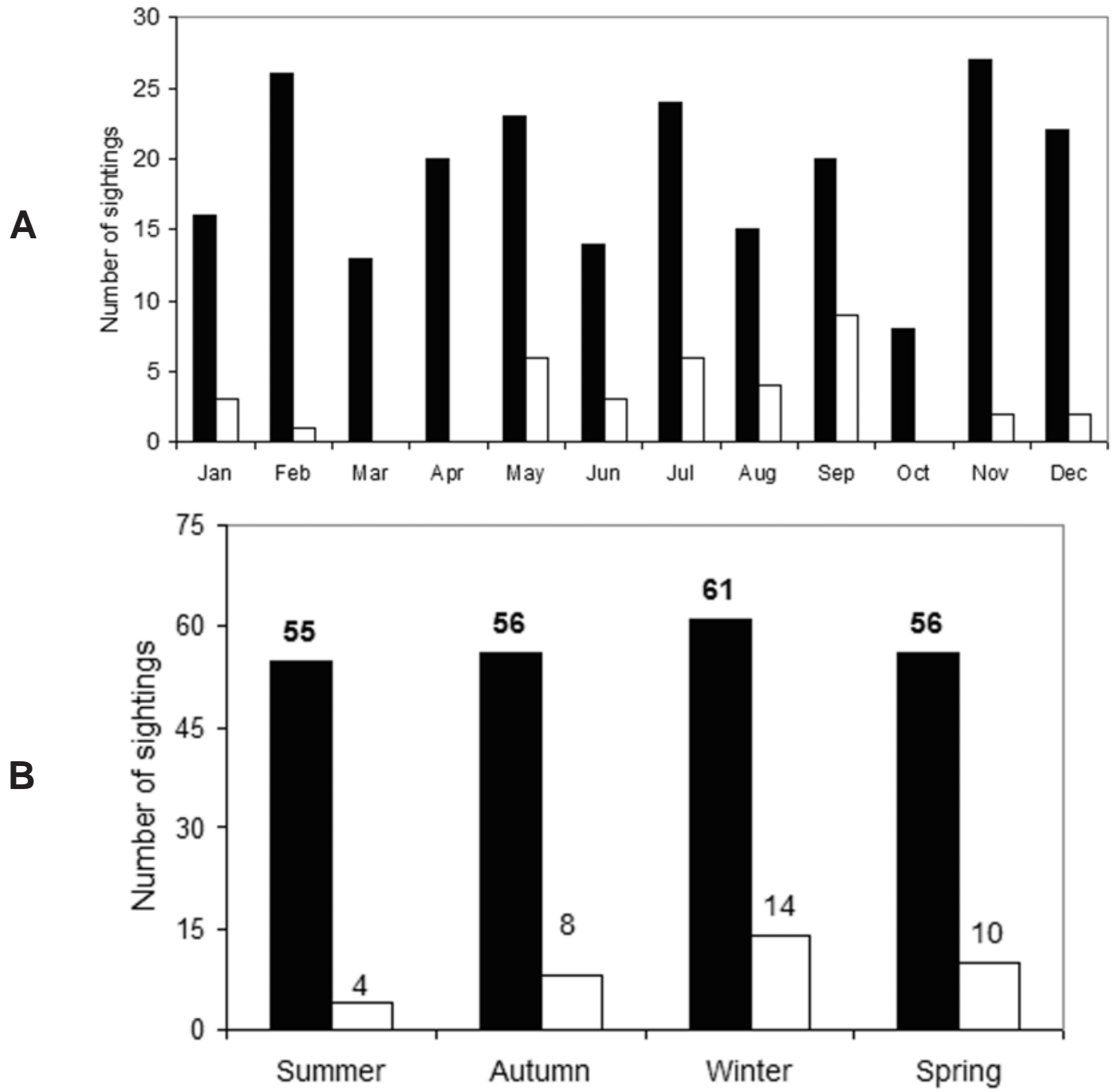

Figure 5. Distribution of sightings of marine tucuxi (solid bars) and bottlenose dolphins (open bars) by month (A) and by season (B) in Baía Norte, southern Brazil, during 1993-2002. 


\section{Environmental correlates}

Marine tucuxis occurred in shallow (mean $=4.48 \pm$ $0.08 \mathrm{~m}, \mathrm{SD}=0.95$, range $=2.5-7.20 \mathrm{~m}, n=138)$, turbid $($ mean $=88.1 \pm 2.56 \mathrm{~cm}, \mathrm{SD}=26.95$, range $=30-175 \mathrm{~cm}, n$ $=111)$, relatively warm $\left(\right.$ mean $=21.9 \pm 0.28^{\circ} \mathrm{C}, \mathrm{SD}=3.57$, range $=13.5-28^{\circ} \mathrm{C}, n=157$ ) waters.

Sightings of bottlenose dolphins occurred also in shallow waters (mean $=4.7 \pm 0.37 \mathrm{~m}, \mathrm{SD}=1.91$; range $=2-9.5 \mathrm{~m}, n=26$ ) but less turbid (mean $=111.5 \pm$ $13.07 \mathrm{~cm}, \mathrm{SD}=50.62$, range $=54-239 \mathrm{~cm}, n=15)$ and relatively colder $\left(\right.$ mean $=20.8 \pm 0.88^{\circ} \mathrm{C}, \mathrm{SD}=3.94$ range $\left.=15-27^{\circ} \mathrm{C}, n=20\right)$, but none of these differences was significant (Mann-Whitney $U$ test: water temperature $P=0.2641$, depth $P=0.8961$, transparency $P=0.118)$.

Group size and composition

Marine tucuxi group size was large $(\mathrm{N}=60-80$ individuals) and roughly the same size class (class 6) in most sightings (84.6\%, N = 181 sightings) (Figure 6A).
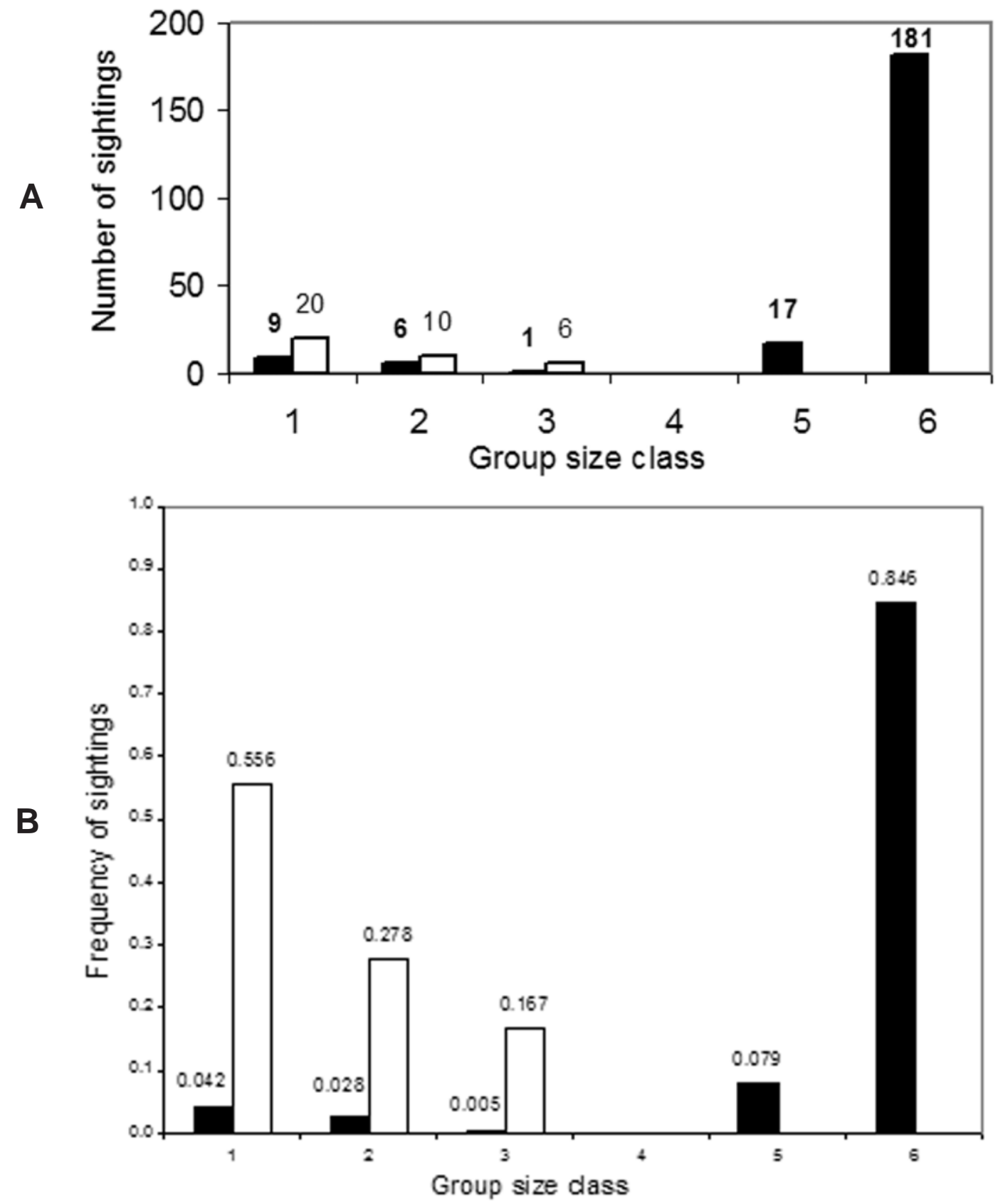

Figure 6. A - Group size of marine tucuxi (solid bars) and bottlenose dolphins (open bars) in Baía Norte, southern Brazil, during $1993-$ 2002. B - Group size classes: class 1 - one to 5 individuals, class 2 - six to ten individuals, class $3-11$ to 20 idividuals, class $4-21$ to 40 individuals, class $5-41$ to 60 individuals, and class $6-61$ to 80 individuals. 
The majority of bottlenose sightings $(86.11 \%, \mathrm{~N}=31$ sightings) were of small group size (Figure 6B). Group size in bottlenose dolphins ranged from 1 to 16 individuals $($ mean $=5.4 \pm 0.7, \mathrm{SD}=4.3$ ).

Marine tucuxi group size was constant throughout the seasons (ANOVA; $\mathrm{P}=0.670$ ), and while bottlenose dolphin small group size (1-5 individuals) occurred mostly in autumn, winter and spring, there was no seasonal difference in group size (ANOVA, $\mathrm{P}=0.301$ ).

Most of marine tucuxi sightings was composed of all age classes (95.5\%, $\mathrm{N}=213$ sightings) with very low frequencies of groups containing adults and calves only $(0.9 \%, \mathrm{~N}=2)$, adults and juveniles $(1.3 \%, \mathrm{~N}=3)$ or lone adults $(2.2 \%, \mathrm{~N}=5)$. There was no seasonal variation in group composition.

In contrast, only $5.6 \%(\mathrm{~N}=2)$ of bottlenose dolphin sightings were of all age classes, while 55.6\% ( $\mathrm{N}=20)$ comprised only adults. Groups composed of adults and calves constituted 25\% ( $\mathrm{N}=9$ ) of all sightings whereas those of adults and juveniles corresponded to $13.9 \%$ (N $=5$ ) of sighted groups.

\section{Interspecific interactions}

Concurrent sightings of both species were recorded on 19 days ( $\mathrm{n}=24$ sightings). Mean distance between tucuxi and bottlenose sighting locations was $6.9 \mathrm{~km}$ (SD = $2.8 \mathrm{~km}$, range $=0.185-15.1 \mathrm{~km})$.

Only twice were tucuxis and bottlenose dolphins seen near each other. In June 1999, a group of two adult bottlenose dolphins approached the area being used for feeding by the group of 60-80 tucuxis (zone EDC). When they were within $185 \mathrm{~m}$ of the tucuxis (later measurement - see Methods), the bottlenose dolphins moved out of the area and crossed the bay to its eastern sector through zones CAA and PDD, respectively. On 8 December 2001, a tucuxi group of 60-80 individuals that was previously feeding, left zone EDC when a group of 12 bottlenose dolphins, containing three possible adult males, came in. When the bottlenose dolphins were still about $200 \mathrm{~m}$ away from but moving toward, the tucuxis immediately started travelling in high speed and porpoising to the opposite direction, then leaving zone EDC to the south toward zone COA. The three large possible male bottlenose dolphins were always in the front of the bottlenose group, which afterwards continued patrolling the coast to the North.

On 22 September 2000, a large tucuxi individual was observed and photographed with about $70 \%$ of its body covered by scars from tooth rakes (Figure 7A) larger and deeper than the usual rakes left by other tucuxis (Figure 7B). Although the animal was feeding with a group of other tucuxis, it was moving slower, breathing more often than other adults as well as avoiding the research boat. Analysis of the photographs suggested that this marine tucuxi might have been attacked by bottlenose dolphin(s) as tooth rake spacing (Figure 7A) matched those of a bottlenose but not a marine tucuxi. Measurements were taken from tooth rakes in the photographs in Figure 7 enlarging dorsal fin height to those of an adult marine tucuxi found stranded in the region. The distance of middle of each tooth alveolus to tbe next one from mandibles was also measured from skull samples randomly selected for bottlenose dolphins and marine tucuxis available in a scientific collection. Tooth rakes in Figure $7 \mathrm{~A}$ was about $1.0 \mathrm{~cm}$, fitting the mean tooth separation for bottlenose (mean $=1.14 \mathrm{~cm}$, $\mathrm{N}=10, \mathrm{SD}=0.09$ ) but not for marine tucuxi (mean = $0.57 \mathrm{~cm}, \mathrm{~N}=10, \mathrm{SD}=0.02$ ).

No predation on either marine tucuxi or bottlenose dolphins was recorded. However, a large tucuxi (photoidentified by notches on the dorsal fin since at least January 1997) was observed and photographed in July 2001 bearing fresh shark bites on both sides of the tail stock behind the dorsal fin. The wounds became completely healed by September 2001, and this adult was subsequently sighted and photographed until July 2002.

Both tucuxis and bottlenose dolphins were seen feeding on the same fish species (white mullet Mugil curema and southern anchovy Lycengraulis grossidens) on the same days. Additionally, feeding on the Atlantic cutlassfish (Trichiurus lepturus) has also been observed on few occasions by both dolphin species though on different days.

\section{Discussion}

Marine tucuxis commonly occur year round in bays and estuarine systems (e.g. da Silva and Best, 1996; Flores, 2002), as reported here. However, such discrete or restricted distribution as in Baía Norte is unusual when compared to other areas (e.g. Geise et al., 1999; Lodi, 2003; Azevedo et al., 2005). In Baía Norte, marine tucuxis were clearly found in and nearby the $3 \mathrm{~m}$-depth contour only at the western (mainland) sector of the bay. The species may then use the depth contour as a 'indicator moving lane' between core or important areas of feeding for example, as suggested by Flores and Bazzalo (2004).

Bottlenose dolphins but not marine tucuxis have been frequently seen in almost all beaches at the open ocean coast of Santa Catarina Island during the study period. This apparent lack of marine tucuxi sightings off the Island also helps to corroborate the hypotheses of a very discrete, restricted distribution of marine tucuxi in Baía Norte.

Some of these results may be seen with caution due to the possible dependency of uneven distribution of field effort. However, it may seem unlikely due to the extensive field effort and further data on high levels of residency and site fidelity (Flores, 1999; 2003; Flores and Bazzalo, 2004). 

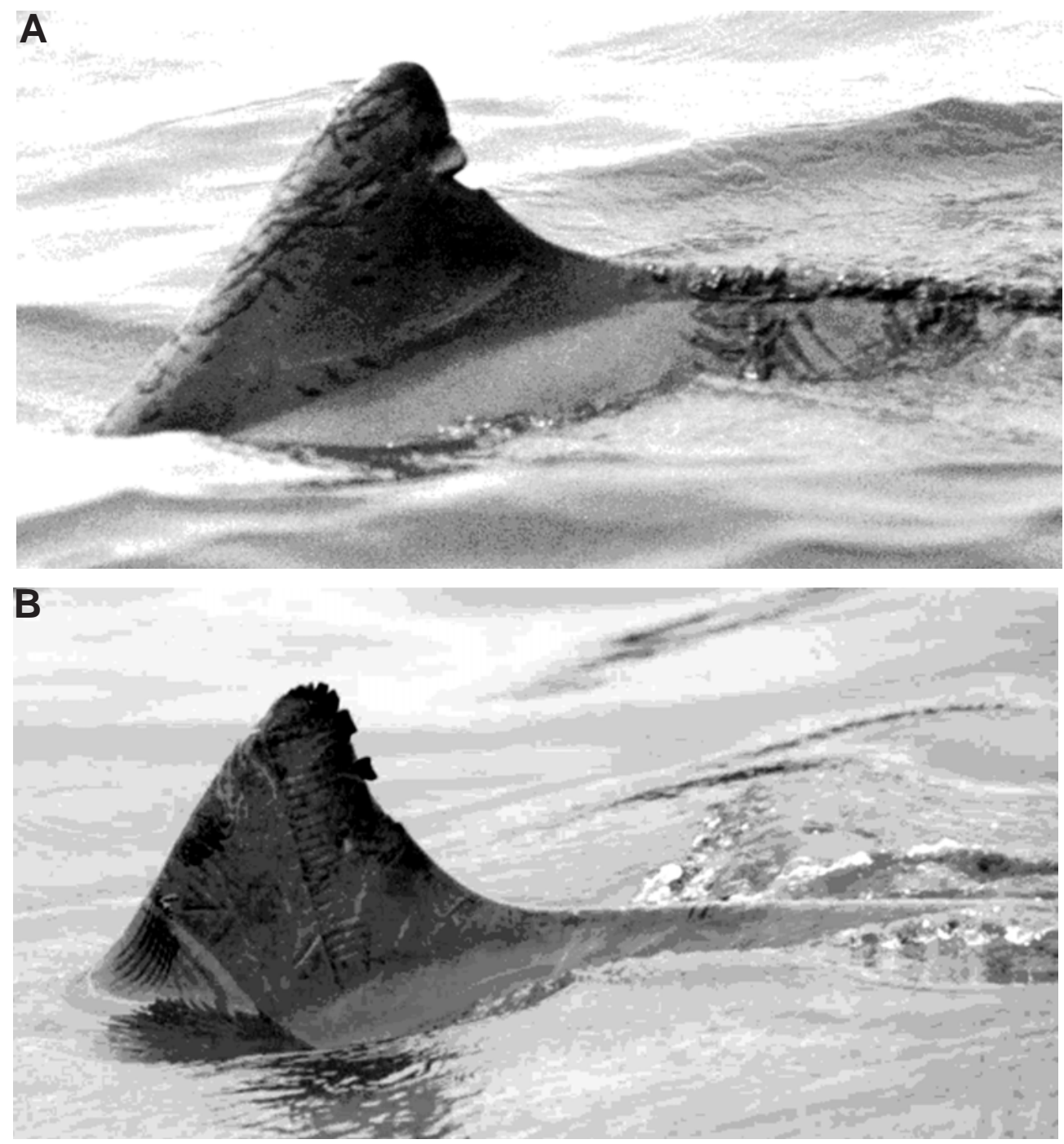

Figure 7. Marine tucuxis photographs in Baía Norte, SC, southern Brazil: A) Adult apparently attacked by bottlenose dolphins; B) 'Typical' adult bearing tooth rakes from conspecifics. Photographs by Paulo A.C. Flores.

In Baía Norte, marine tucuxis occurred in shallow waters similarly to what has been reported from other locations. Marine tucuxis rarely venture to waters deeper than $5 \mathrm{~m}$ and are usually seen in areas shallower than $2 \mathrm{~m}$ in the Kayos Miskito Reserve, Nicaragua (Edwards and Schell, 2001). However, in other areas marine tucuxis may preferentially be found in deeper waters such as in Guanabara Bay, where they occur in depths $>5 \mathrm{~m}$ and up to 23m, rarely in 1-3m (Andrade et al., 1987; Geise et al., 1999) but more recently found at 3.5-34m (Azevedo et al., in press). In the Cananéia estuarine system, tucuxi uses preferentially waters up to $23 \mathrm{~m}$ deep (Santos, 2004).

Borobia et al. (1991) proposed that low sea-surface temperature might act as a geographical barrier and also contribute to the larger body size of the marine species compared to the riverine tucuxi (Sotalia fluviatilis). Water temperature did not affect marine tucuxi distribution in Baía Norte as dolphins were present in the same area throughout seasons, through a temperature range of $14.5^{\circ} \mathrm{C}$.
Mean values of environmental variables measured here (water temperature, turbidity, depth) did not differ between areas of occurrence of marine tucuxi and bottlenose dolphins. Nevertheless, the former spent most if not all of the time in Baía Norte, while the latter were sighted only a few times. So, there might be differences in habitat preferences between the two species. Lack of differences in environmental conditions in the areas of occurrence of the two species within Baía Norte might be due to the similarity in the entire study area.

On the other hand, bottlenose dolphin group size and composition in Baía Norte is similar to other coastal areas (e.g. see review in Wells and Scott, 1999), including Brazilian waters. In the river and lagoon systems as well as in the nearby coastline off Laguna, southern Brazil, group size ranged from one to 10 individuals (SimõesLopes, 1995) and in Patos Lagoon mean group size was $4.4(\mathrm{SD}=2.44, \mathrm{n}=177)$ (Dalla Rosa, 1999). 
Groups containing all age classes are not common in marine tucuxi at least in the Cananéia region (Geise et al., 1999; Santos, 2004), and Babitonga Bay (Cremer, 2000). In Paraty and Guanabara Bays, southeastern Brazilian coast, however, groups with different age classes may be found more often although such are considered temporary feeding grouping (Azevedo et al., 2005; Lodi, 2003). Given that large groups (category 6) were the most frequent in Baia Norte it is very likely that all age classes are present in such groups. It is worth mentioning once again the probable influence of different definitions and methods applied in each study to the differences in group composition discussed here.

No mixed-group or positive interactions as reported by Acevedo-Gutierrez et al. (2005), were recorded between the marine tucuxi and the bottlenose dolphin on the only two occasions in which they were sighted near each other in Baía Norte. Also, in a previous land-based study with marine tucuxis in Baía Norte, no encounter was recorded in about 360hs of dolphins' direct observations out of 430hs of effort in 1991-92 (Flores, 1992). It is likely then that aggression may represent the interaction pattern for these species during rare associations in Baía Norte. Factors leading to this suggestion include the high survey effort and focal group sampling (or observation time) of both species, the observation of tucuxi displacement by bottlenose presence and the probable bottlenose dolphin(s) attack on a large tucuxi suggested by the tooth scarring pattern in the latter (Figure 7A) reported here. The latter is combined with the anedoctal report of an aggression event reported by Wedekin et al. (2004). The tooth scarring in the adult marine tucuxi (Figure 7A) clearly resembles those shown from a captive male Sotalia attacked by bottlenose dolphins (Terry, 1984), adding further evidence of an attack by the latter.

The difference in bottlenose dolphin group size during the two events of close proximity to the marine tucuxi reported here may help to explain the different interaction patterns observed. Two animals may not form a strong enough unit to challenge and defeat a large group of an even smaller potential opponent. On the other hand, the larger group of 12 bottlenose dolphins could form such a powerful unit and then displace marine tucuxis right away. Other factors such as dolphin activities and individuals involved in the encounter are likely to play important role in the development of the interaction (e.g. Herzing and Johnson, 1997; Acevedo-Gutierrez et al., 2005).

The findings reported here indicate that in the study area mixed groups of bottlenose and marine tucuxi dolphins do not occur. They also suggest that bottlenose dolphins may behave aggressively toward marine tucuxis as it has been recorded for other species elsewhere. Aggression toward or dominance over humpback dolphins (Sousa chinensis) by bottlenose dolphins was recorded in Australia and South Africa (Saayman and Tayler, 1979; Corkeron, 1990). Bottlenose dolphins exhibited aggression to the Atlantic spotted dolphin Stenella frontalis in the Bahamas (Herzing and Johnson, 1997) and the harbor porpoise (Phocoena phocoena) in northern Scotland (Ross and Wilson, 1996). Extreme infanticide evidences by bottlenose dolphins on the latter led Patterson et al. (1998) to suggest that infanticide should also be considered another factor influencing behavior and social structure in cetaceans. There is no evidence of such infanticide in our study and more detailed investigation of dead tucuxis found in Baía Norte along with continued observation of free-ranging animals are needed to assess this and to what extent aggression is occurring.

The observed feeding on the same fish species by both marine tucuxis and bottlenose dolphins would indicate food competition. Stomach contents of few stranded animals of both species ( $n=3$ adults for each species) from the study area show they prey on white mullets (Emerin, 1994). Such diet overlap was also reported to the southeastern Brazilian coast through analysis of stranded or incidentally caught specimens both in the Atlantic cutlassfish (Santos et al., 2002) as well as in cephalopods (Santos and Haimovici, 2001). Such evaluation should be taken with caution, however, because of the shortcomings of evaluating cetacean feeding habits exclusively through stranded specimens as discussed by Barros and Odell (1990). In southsoutheastern Brazil, the marine tucuxi feeds on a variety of prey belonging to various families (Sciaenidae, Eugraulidae, Trichiuridae and Mugilidae, among others) though it has a marked preference for demersal, Sciaenidae fishes (e.g. Santos and Haimovici, 2001; Santos et al., 2002). Such flexibility in feeding is also a feature in the bottlenose dolphin (Wells and Scott, 1999). Some of these are also prey items of bottlenose dolphins in this area (e.g. Emerim, 1994; Santos and Haimovici, 2001, Santos et al., 2002). Most of these fishes such as the white mullet, the banded ground stardrum (Paralonchurus brasiliensis), the rake stardrum (Stellifer rastrifer), the Atlantic cutlassfish (Trichiurus lepturus) and the whitemouth croaker (Micropogonias furnieri) seem to be quite abundant and are captured by both artisanal and industrial fisheries in Baía Norte (e.g. CEPSUL - IBAMA 19984, UNIVALI 20015 , 20026).

\footnotetext{
${ }^{4}$ CEPSUL-IBAMA (1998) Informe da pesca extrativa marinha em Santa Catarina de 1995 a 1996. Instituto Brasileiro do Meio Ambiente e dos Recursos Naturais Renováveis - Centro de Pesquisa e Extensão Pesqueira das Regiões Sul e Sudeste, Itajaí, SC, Brazil.

${ }^{5}$ UNIVALI (2001) Boletim estatístico da pesca industrial de Santa Catarina ano 2000: ações prioritárias ao desenvolvimento da pesca e aqüicultura no sul do Brazil. Universidade do Vale do Itajaí, Itajaí, SC, Brazil.

${ }^{6}$ UNIVALI (2002) Boletim estatístico da pesca industrial de Santa Catarina ano 2001: ações prioritárias ao desenvolvimento da pesca e aqüicultura no sul do Brazil. Universidade do Vale do Itajaí, Itajaí, SC, Brazil.
} 
Interspecies competition depend upon spatial and temporal overlap in distribution of the species, diet overlap in items consumed as well as scarcity or dispersed distribution of such prey items (e.g. Begon et al., 2006). Marine tucuxis and bottlenose dolphins apparently rarely meet but might prey on the same fish species. Food competition between these dolphins though apparently unlikely may stands at least as a possibility in this region, pending further investigation.

Biological and ecological aspects such as differential habitat preferences, potential inter-specific aggression, predator avoidance and food competition might help to explain the parapatrical distribution of marine tucuxis and bottlenose dolphins in Baía Norte and should be investigated.

\section{Acknowledgments}

The study has been funded by Earthwatch Institute, Whale and Dolphin Conservation Society, Cetacean Society International and Fundação O Boticário de Proteção à Natureza. Small grants were donated by Sociedade de Pesquisa e Educação Ambiental (Brazil), The Humane Society of the United States, the Society for Marine Mammalogy and IdeaWild (USA). Especial thanks to Bill Rossiter (Cetacean Society International) and José Truda Palazzo Jr. (International Wildlife Coalition Brazil) for continued support and encouragement. During 1999-2003 PACF recieved a scholarship from Conselho Nacional de Desenvolvimento Científico e Tecnológico (CNPq Proc. 146609/1999-9). We thank the Earthwatch volunteers and our staff Marcia Riederer, Daniela Fettuccia and Mariel Bazzalo as well as interns Luciana T. Barros and Mariana Graciosa for invaluable boat and lab work - especially to M. Bazzalo for her almost tireless help in data reducing and analysis as well as figure and map preparation. Paulo C. SimõesLopes allowed access to the scientific collection under his care for tooth alveoli measurements. Earlier drafts of this manuscript were improved by discussions and suggestions from Mariel Bazzalo, Denise L. Herzing, Paulo H. Ott, Marcos C.O. Santos, Eduardo R. Secchi, Nélio B. Barros and Randall S. Wells. We appreciate the reviews and comments from Alexandre F. Azevedo and an anonymous referee who made important contributions to the final manuscript.

\section{References}

Acevedo-Gutierrez, A., Di Berardinis, A., Larkin, S., Larkin, K. AND ForestelL, P. (2005) Social interactions between tucuxis and bottlenose dolphins in Gandoca-Manzanillo, Costa Rica. Latin American Journal of Aquatic Mammals 4(1): 49-54.

Azevedo, A.F., Viana, S.C., Oliveira, A.M. and Van Sluys, M. (2005) Group characteristics of marine tucuxis (Sotalia fluviatilis) (Cetacea: Delphinidae) in Guanabara Bay, southeastern Brazil. Journal of the Marine Biological Association of the United Kingdom 85: 209-212.
Azevedo, A.F., Oliveira, A.M., Viana, S.C. and Van Sluys, M. (in press) Habitat use by marine tucuxis (Sotalia guianensis) (Cetacea: Delphinidae) in Guanabara Bay, south-eastern Brazil. Journal of the Marine Biological Association of the United Kingdom 87: 201-205.

BARROS, N.B. AND ODELL, D.K. (1990) Food habits of bottlenose dolphins in the southeastern United States. Pages 309-329 in Leatherwood, S. and Reeves, R.R. (Eds) The Bottlenose Dolphin. Academic Press, San Diego, CA, USA. 653 pp.

Bastida, R., Rodriguez, D., Secchi, E.R. and da Silva, V.M.F. (in press) Mamíferos Acuáticos de Sudamérica y Antártida. Vazquez Mazzini Editores, vol.1. Buenos Aires, Argentina. 360pp.

Begon, M., Colin, R.T. and Harper, J.L. (2006) Ecology: from Individuals to Populations. $4^{\text {th }}$ Edition. Blackwell Publishing, Malden, MA, USA. 738 pp.

Borobia, M., Siciliano, S., Lodi, L. ANd Woek, W. (1991) Distribution of the South American dolphin Sotalia fluviatilis Canadian Journal of Zoology 69: 1025-1039.

CorKeron, P.J. (1990) Aspects of the behavioral ecology of inshore dolphins Tursiops truncatus and Sousa chinensis in Moreton Bay, Australia. Pages 285-294 in LeATHERWOOD, S. AND Reeves, R.R. (Eds) The Bottlenose Dolphin, Academic Press, San Diego, CA, USA. 653 pp.

Dalla Rosa, L. (1999) Estimativa do tamanho da população de botos, Tursiops truncatus, do estuário da Lagoa dos Patos, RS, a partir da foto-identificação de indivíduos com marcas naturais e da aplicação de modelos de marcação-recaptura. M.Sc. Thesis, Fundação Universidade Federal do Rio Grande. Rio Grande, RS, Brazil. 104 pp.

DA Silva, V.M.F. ANd Best, R.C. (1996) Sotalia fluviatilis. Mammalian Species 527: 1-7.

Di Beneditto, A.P.M., Ramos, R.M.A. AND Lima, N.R.W. (2001) Sightings of Pontoporia blainvillei (Gervais \& D'Orbigny, 1844) and Sotalia fluviatilis (Gervasi, 1853) (Cetacea) in South-eastern Brazil. Brazilian Archives of Biology and Technology 44: 291-296.

EDWARDS, H.H. AND ScHNELL, G.D. (2001) Status and ecology of Sotalia fluviatilis in the Cayos Miskito Reserve, Nicaragua. Marine Mammal Science 17: 445-472.

EMERIN, E.G. (1994) Contribuição para o conhecimento dos hábitos alimentares de delfínideos (MAMMALIA, CETACEA, ODONTOCETI, DELPHINIDAE) nas proximidades da Itha de Santa Catarina, SC, Brasil. B.Sc. Monograph. Universidade Federal de Santa Catarina, Florianópolis, SC, Brazil. 45 pp.

Flores, P.A.C. (1992) Observações sobre movimentos, comportamento e conservação do golfinho ou boto Sotalia fluviatilis (Gervais, 1853) (Mammalia-Cetacea-Delphinidae) na Baía Norte de Santa Catarina, SC, Brasil. B.Sc. Monography, Universidade Federal de Santa Catarina, Florianópolis, SC, Brazil. 48 pp.

FLORES, P.A.C. (1999) Preliminary results of a photoidentification study of the marine tucuxi Sotalia fluviatilis in southern Brazil. Marine Mammal Science 15: 840-847.

Flores, P.A.C. (2002) Tucuxi (Sotalia fluviatilis). Pages 1267-1269 in Perrin, W.F., Würsig, B. \& TheWISSEn, J.G.M. (Eds.) Encyclopedia of Marine Mammals, Academic Press, San Francisco, CA, USA.

FLORES, P.A.C. (2003) Ecology of the marine tucuxi dolphin (Sotalia fluviatilis) in southern Brazil. Ph.D. Thesis. Pontifícia Universidade Católica do Rio Grande do Sul, Porto Alegre, RS, Brazil. 141 pp. 
Flores, P.A.C. and Bazzalo, M. (2004) Home ranges and movements patterns of the marine tucuxi Sotalia fluviatilis in Baía Norte, southern Brazil. Latin American Journal of Aquatic Mammals 3(1): 37-52.

Flores, P.A.C., Sousa-Lima, R.S. And Siqueira, G.S. (2000) Avistagens de franciscana (Pontoporia blainvillei) na Baía Norte, Santa Catarina, Sul do Brasil. Pages 71-74 in Report of the Third Workshop for Coordinated Research and Conservation of the Franciscana Dolphin (Pontoporia blainvillei) in the Southwestern Atlantic, UNEP/CMS, 112p. Available through UNEP/CSM Secretariat, Martin Luther King St. 8, Bonn, Germany, 53175.

Geise, L., Gomes, N. And Cerqueira, R. (1999) Behaviour, habitat use and population size of Sotalia fluviatilis (Gervais, 1853) (Cetacea, Delphinidae) in the Cananéia estuary region, São Paulo, Brazil. Revista Brasileira de Biologia 59: 183-194.

Herzing, D.L. and Johnson, C.M. (1997) Interspecific interactions between Atlantic spotted dolphins (Stenella frontalis) and bottlenose dolphins (Tursiops truncatus) in the Bahamas, 1985-1995. Aquatic Mammals 23: 85-99.

IBAMA (2001) Mamíferos Aquáticos do Brasil: Plano de Ação. Instituto Brasileiro do Meio Ambiente e dos Recursos Naturais Renováveis, Brasília, DF, Brazil. 79 pp.

LoDI, L. (2001) Tamanho e composição de grupo dos botoscinza, Sotalia guianensis (van Bénéden, 1864) (CETACEA, DELPHINIDAE), na Baía de Paraty, Rio de Janeiro, Brasil. Atlântica, Rio Grande 25(2): 135-146.

Lodi, L. (2003) Seleção e uso do hábitat pelo boto-cinza, Sotalia guianesis, na baía de Paraty, Rio de Janeiro, Brasil. Revista Bioikos, PUC-Campinas, 17 (1/2): 5-20.

Lodi, L. And Hetzel, B. (1998) Grandes agregações do botocinza (Sotalia fluviatilis) na Baía da Ilha Grande, Rio de Janeiro. Revista Bioikos, PUC-Campinas, 12: 26-30.

Monteiro Filho, E.L.A., Bonin, C.A. and Rautenberg, M. (1999) Interações interespecíficas dos mamíferos marinhos na região da Baía de Guaratuba, litoral sul do estado do Paraná. Biotemas 12: 119-132.

Patterson, I.A.P., Reid, R.J., Wilson, B., Grellier, K., Ross, H.M. And Thompson, P.M. (1998) Evidence for infanticide in bottlenose dolphins: an explanation for violent interactions with harbour porpoises? Proceedings of the Royal Society of London B 265: 1-4.

Ross, H.M. AND WiLson, B. (1996) Violent interactions between bottlenose dolphins and harbour porpoises. Proceedings of the Royal Society of London B 263: 283-286.
SaAyman, G.S. and TAYler, C.K. (1979) The socioecology of humpback dolphins (Sousa sp.). Pages 165-226 in WINN, H.E. AND Olla, B.L (Eds) Behavior of Marine Mammals, Vol. 2, Cetacean. Plenum Press, New York, NY, USA.

SANTos, M.C.O. (2004) Uso de área e organização social do bototucuxi marinho, Sotalia fluviatilis (Cetacea, Delphinidae), no estuário de Cananéia, SP. Ph.D. Thesis, Universidade de São Paulo, São Paulo, SP, Brazil. 265 pp.

Santos, M.C.O., Rosso, S., Santos, R.A., Lucato, S.H.B. and BAssoI, M. (2002) Insights on small cetacean feeding habits in southeastern Brazil. Aquatic Mammals 28: 38-45.

Santos, R.A. And Haimovici, M. (2001) Cephalopods in the diet of marine mammals stranded or incidentally caught in southeastern and southern Brazil $\left(21-34^{\circ} \mathrm{S}\right)$. Fisheries Research 52: 99-112.

SimÕEs-Lopes, P.C. AND FABiÁN, M.E. (1999) Residence patterns and site fidelity in bottlenose dolphins, Tursiops truncatus (Monatagu) (Cetacea, Delphinidae) off southern Brazil. Revista Brasileira de Zoologia 16: 1017-1024.

Simões-Lopes, P.C., Fabián, M.E. and Menegheti, J.O. (1998) Dolphin interactions with the mullet artisanal fishing on southern Brazil: a qualitative and quantitative approach. Revista Brasileira de Zoologia 15: 709-726.

SMolker, R.A., Richards, A.F., ConNor, R.C. And Pepper, J.W. (1992) Sex differences in patterns of association among Indian Ocean bottlenose dolphins. Behaviour 123: 38-69.

TERrY, R.P. (1984) Intergeneric behavior between Sotalia fluviatilis guianensis and Tursiops truncatus in capitvity. Zeitschrift für Säugetierkunde 49: 290-299.

Tolley, K.A., Read, A.J., Wells, R.S., Urian, K.W., Scott, M.D., Irvine, A.B. AND HoHn, A.A. (1995) Sexual dimorphism in wild bottlenose dolphins (Tursiops truncatus) from Sarasota, Florida. Journal of Mammalogy 76: 1190-1198.

Wedekin, L.L., Daura-Jorge, F.G. And Simões-Lopes, P.C. (2004) An aggressive interaction between bottlenose dolphins (Tursiops truncatus) and estuarine dolphins (Sotalia guianensis) in southern Brazil. Aquatic Mammals 30(3): 391-397.

Wells, R.S. AND SCOTT, M.D. (1999) Bottlenose dolphin Tursiops truncatus (Montagu 1821). Pages 137-182 in RIDGWAY, S.H. AND Harrison, R.J. (Eds) Handbook of Marine Mammals, Vol. 6, The Second Book of Dolphins and Porpoises. Academic Press, San Diego, CA, USA.

ZAR, J.H. (1999) Biostatistical Analysis. $4^{\text {th }}$ edition. Prentice Hall, Upper Saddle River New Jersey. 